\title{
Liver-derived IGF1 enhances the androgenic response in prostate
}

\author{
Johan Svensson, Jon Kindblom ${ }^{1}$, Ruijin Shao ${ }^{2}$, Sofia Movérare-Skrtic, Marie K Lagerquist, \\ Niklas Andersson, Klara Sjögren, Katrien Venken ${ }^{3}$, Dirk Vanderschueren ${ }^{3}$, John-Olov Jansson, \\ Olle Isaksson and Claes Ohlsson
}

Division of Endocrinology, Department of Internal Medicine, Sahlgrenska Academy, Sahlgrenska University Hospital, Göteborg University, Gröna Stråket 8, SE-413 45 Göteborg, Sweden

${ }^{1}$ Department of Oncology, Sahlgrenska University Hospital, SE-41345 Göteborg, Sweden

${ }^{2}$ Department of Physiology/Endocrinology, Institute of Neuroscience and Physiology, The Sahlgrenska Academy at Göteborg University, SE-40530 Göteborg, Sweden

${ }^{3}$ Laboratory for Experimental Medicine and Endocrinology, Department of Experimental Medicine, Katholieke Universiteit Leuven, Box 902 , B-3000 Leuven, Belgium

(Correspondence should be addressed to J Svensson; Email: johan.svensson@medic.gu.se)

\begin{abstract}
Both IGF1 and androgens are major enhancers of prostate growth and are implicated in the development of prostate hyperplasia and cancer. The aim of the present study was to investigate whether liver-derived endocrine IGF1 modulates the androgenic response in prostate. Mice with adult, liverspecific inactivation of IGF1 (LI-IGF1 ${ }^{-/-}$mice) displayed an $\sim 80 \%$ reduction in serum IGF1 levels associated with decreased prostate weight compared with control mice (anterior prostate lobe $-19 \%, P<0 \cdot 05$; dorsolateral prostate (DLP) lobe $-35 \%$, $P<0 \cdot 01$; ventral prostate $(\mathrm{VP})$ lobe $-47 \%, P<0 \cdot 01)$. Reduced androgen receptor $(A r)$ mRNA and protein levels were observed in the VP lobe $(-34 \%$ and $-30 \%$ respectively, both $P<0.05$ versus control mice). Analysis of prostate morphology showed reductions in both the glandular and fibromuscular
\end{abstract}

compartments of the VP and DLP lobes that were proportional to the reductions in the weights of these lobes. Immunohistochemistry revealed reduced intracellular AR immunoreactivity in the VP and DLP lobes. The non-aromatizable androgen dihydrotestosterone increased VP weight to a lesser extent in orchidectomized (ORX) LI-IGF1 ${ }^{-\prime}$ mice than in ORX controls $(-40 \%, P<0 \cdot 05$ versus control mice). In conclusion, deficiency of liver-derived IGF1 reduces both the glandular and fibromuscular compartments of the prostate, decreases AR expression in prostate, and reduces the stimulatory effect of androgens on VP weight. These findings may explain, at least in part, the well-known clinical association between serum IGF1 levels and conditions with abnormal prostate growth.

Journal of Endocrinology (2008) 199, 489-497

\section{Introduction}

The GH/IGF1 axis as well as androgens is involved in the regulation of prostate size and is implicated in the development of prostate cancer (Djavan et al. 2001, Jerome et al. 2003, Lam et al. 2006, Samani et al. 2007). However, little is known of the in vivo interaction between the GH/ IGF1 axis and androgens for the regulation of prostate growth (Djavan et al. 2001, Jerome et al. 2003, Samani et al. 2007).

Clinical and experimental studies have demonstrated that both GH and IGF1 have the capacity to increase prostate size, but it is unclear whether all of the effect of $\mathrm{GH}$ on prostate size is mediated via IGF1 (Colao et al. 1998, 2003). In humans, several population-based epidemiological studies suggest a positive association between high circulating IGF1 levels and risk of prostate cancer (Mantzoros et al. 1997, Chan et al. 1998, Wolk et al. 1998). By contrast, a high serum level of IGF-binding protein-3 (IGFBP3) appears to protect against the development of prostate cancer (Kanety et al. 1993, Chan et al. 1998). A high IGF1/IGFBP3 ratio has, therefore, been suggested to be a risk factor for prostate cancer (Djavan et al. 2001). Acromegalic patients have excess GH, increased prostate size (Colao et al. 1998), and increased risk of colorectal cancer (Orme et al. 1998), but no increase in prostate cancer (Orme et al. 1998). The latter could be due to the fact that not only serum IGF1 levels but also serum IGFBP3 levels are increased in these patients (Djavan et al. 2001). The assumption that the IGF1 system is involved in prostate cancer is supported by the fact that prostate-specific antigen, an established biomarker for prostate cancer, cleaves and inactivates IGFBP3 (Cohen et al. 1992, 1994b), thereby enhancing the bioavailability of IGF1.

In vitro studies have demonstrated that several components of the IGF1 system are involved in the regulation of the growth of prostate-derived cells (Perkel et al. 1990, Cohen et al. 1991, 1994a,b,c). In primary culture, the prostatic epithelial cells express the IGF1 receptor and IGF1 stimulates them to proliferate and to produce IGFBPs into the medium 
(Perkel et al. 1990, Cohen et al. 1991). Prostatic stromal cells also express the IGF1 receptor (Cohen et al. 1994a,b,c), and there is local production of IGF1 in these cells (Kaplan et al. 1999, Meinbach \& Lokeshwar 2006). The locally produced IGF1 from the stromal cells can act in a paracrine fashion on the prostatic epithelial cells (Meinbach \& Lokeshwar 2006), which raises the possibility that locally produced IGF1, rather than circulating IGF1, could be important for prostate growth.

The major part of serum IGF1 is liver derived (Sjögren et al. 1999, Yakar et al. 1999). A mouse model with liver-specific, inducible inactivation of the Igf1 gene, using the Cre-LoxP conditional knockout system, has been developed (LI-IGF1 ${ }^{-/-}$ mice; Sjögren et al. 1999, 2001, 2002, Tivesten et al. 2002). The selective inactivation of the Igf1 gene in the liver results in an $\sim 80 \%$ reduction in circulating IGF1. The expression of IGF1 in peripheral tissues is not reduced (Sjögren et al. 1999), and the LI-IGF1 ${ }^{-/-}$mice do not have any major disturbance in postnatal growth (Sjögren et al. 1999). The LI-IGF1 ${ }^{-/-}$mice have increased GH secretion secondary to the decrease in serum IGF1 level (geometric mean plasma GH level 3·1 times higher than that in control mice (Sjögren et al. 1999, Wallenius et al. 2001)). In addition, the LI-IGF1 ${ }^{-/-}$mice have unchanged serum concentration of IGFBP1, whereas IGFBP2 and IGFBP3 in serum are decreased (Sjögren et al. 2002).

Thus, it is generally accepted that IGF1 and androgens are two major regulators of prostate size but little is known whether, in vivo, these two pathways converge in the regulation of prostate size. Moreover, there is little information about the relative importance of circulating versus locally produced IGF1 for prostate growth. The aim of the present study was to investigate whether liver-derived endocrine IGF1 modulates the androgenic response in prostate.

\section{Materials and Methods}

\section{Animals}

The Mx-Cre 31 strain and mice with exon 4 of the Igf1 gene flanked by LoxP sites were generated and intercrossed as described previously (Kuhn et al. 1995, Liu et al. 1998, Sjögren et al. 1999). The different genotypes were identified by PCR analyses of DNA from tail biopsies. Mice homozygous for LoxP and heterozygous for $\mathrm{Mx}-\mathrm{Cre}$ were given polyinosinicpolycytidylic acid (PiPc, 6.25 $\mu \mathrm{g} / \mathrm{g}$ body weight; SigmaAldrich Corp. Sweden AB) in three i.p. injections at 4 weeks of age to induce expression of the Cre protein in hepatocytes (Kuhn et al. 1995). This treatment results in a specific and complete inactivation of IGF1 in hepatocytes (Sjögren et al. 1999, 2001, 2002). PiPc-treated littermates, homozygous for LoxP but lacking Mx-Cre, were used as controls. The animals had free access to fresh water and food pellets (B\&K Universal AB, Sollentuna, Sweden). The Ethics Committee of Göteborg University approved this study.
Study design

Experiment 1 Four-month-old male control $(n=8)$ and LI-IGF1 $^{-1-}(n=8)$ mice were killed. The urogenital tract was removed including the seminal vesicles (SVs), coagulating glands, urethra, and bladder. The individual prostate lobes and SVs were then carefully dissected and separated. Dissections were carried out in Hanks buffer, Mg-free (Gibco), under a Nikon dissection microscope. Wet weights of prostate lobes and SVs were obtained by electronic scale immediately upon dissection. The ventral prostate (VP) was then split and one half was used for the determination of androgen receptor (AR) protein level using western blot analysis. The other half, as well as the anterior prostate (AP) and dorsolateral prostate (DLP) lobes, was used for morphological analyses and immunohistochemistry.

Experiment 2 To investigate the effect of androgen stimulation on VP in male LI-IGF1 ${ }^{-/-}$mice, other mice were either sham operated or orchidectomized (ORX) at 3 months of age. At this age, the mice are sexually matured and they no longer grow rapidly but at a slow steady state. Then, the mice received 5-week treatment with either vehicle (V) or the non-aromatizable androgen DHT (45 $\mu \mathrm{g} /$ day) administered via s.c. silastic implants (Silclear Tubing; Degania Silicone, Ltd, Jordan Valley, Israel) in the cervical region (Vandenput et al. 2002). V-treated animals received empty implants. DHT was obtained from Sigma Chemical Co.. At the end of the 5-week treatment, the mice were killed, the blood was collected for the analysis of serum IGF1 level and the wet weight of VP was determined. In addition, in the sham-operated, gonadal intact male control and LI-IGF1 ${ }^{-/-}$ mice, serum levels of testosterone and estradiol were determined, as well as mRNA levels of AR and IGF1, estrogen receptor- $\alpha$, and estrogen receptor- $\beta$ in VP tissue using RT-PCR. The number of animals in each group was as follows: sham operated (control, $n=6$; LI-IGF1 ${ }^{-/-}, n=8$ ); ORX V treated (control, $n=8$; LI-IGF1 ${ }^{-\prime}, n=8$ ); or ORX DHT treated (control, $n=6$; LI-IGF1 ${ }^{-/-}, n=8$ ).

\section{Histology}

Prostate lobes from 4-month-old LI-IGF1 ${ }^{-/-}$and control mice (Experiment 1) were removed as described, and thereafter fixed in 4\% paraformaldehyde in PBS $(\mathrm{pH} \mathrm{7 \cdot 4)}$ overnight, dehydrated, and embedded in paraffin. Fixation times were identical in both groups. The paraffin block was cut into $5 \mu \mathrm{m}$ serial sections. Three adjacent sections from three different levels of each gland were taken to make a single observation. Anatomical analysis was performed on the sections stained with hematoxylin and eosin. Adjacent sections from each level were stained by immunohistochemistry for the detection of AR. 


\section{Immunohistochemistry}

The antibody used to detect AR in this study was raised against human ARs and recognized the ligand-binding domain of AR in rodent tissues (sc-816; Santa Cruz Biotechnology, Inc., Santa Cruz, CA, USA). After deparaffination and rehydration in graded alcohol, the sections were first subjected to heat treatment by using $10 \mathrm{mM}$ sodium citrate buffer $(\mathrm{pH} 7 \cdot 6)$, $10 \mathrm{~min}$ at $95^{\circ} \mathrm{C}$, allowed to cool in the buffer for $\sim 15 \mathrm{~min}$, and then washed with $\mathrm{dH}_{2} \mathrm{O}$. The endogenous peroxidase activity was blocked by incubating in $0.5 \%$ hydrogen peroxide in $\mathrm{dH}_{2} \mathrm{O}$ for $5 \mathrm{~min}$. AR immunoperoxidase staining was performed using the ImmunoCruz staining system (Santa Cruz Biotechnology, Inc.) as described previously (Kindblom et al. 2002, 2003). All tissues from LI-IGF1 ${ }^{-/-}$and control male mice were processed in the same assay to minimize discrepancies due to variance in intensity. Digital photographic imaging was obtained using a CR14 CCD camera (JENOPTIK, Jena, Germany) mounted on an eclipse E800 microscope (Nikon, Tokyo, Japan) and using proprietary imaging software.

\section{Protein extraction and western blot analysis}

The protein preparation of the selected VP lobes was essentially performed as described previously (Shao et al. 2006, 2007). The protein content was determined using the BCA protein assay (Pierce, Rockford, IL, USA). Western blot analyses were performed using standard procedures to evaluate the abundance and distribution of AR (Shao et al. 2007). Fifty micrograms of protein were directly electrophoresed on $4-12 \%$ SDS-polyacrylamide gels (Novex, San Diego, CA, USA) with a Bis-Tris-MOPS buffer system under reducing conditions. After transferring to polyvinyl difluoride membranes (Amersham International), the blots were incubated with 5\% non-fat milk in a Tris-buffered saline-Tween 20 buffer $(10 \mathrm{mM}$ Tris, $150 \mathrm{mM} \mathrm{NaCl}$, and $0 \cdot 1 \%$ Tween $20(\mathrm{pH} 8 \cdot 0))$ for $2 \mathrm{~h}$ and subsequently probed with the AR antibody (at 1:250, sc-816; Santa Cruz Biotechnology, Inc.) in blocking buffer overnight at $4{ }^{\circ} \mathrm{C}$. The following day, the membranes were incubated with alkaline phosphatase-conjugated goat-anti-rabbit antibody (at 1:40 000, AC31RL; Tropix, Bedford, MA, USA) and detected using CDP-Star substrate for alkaline phosphatase system (Tropix). Immunoblotted signals were exposed and developed using ECL film (Amersham International) and subsequently scanned into a computer. Individual bands were quantified directly from membranes by densitometry using the ImageQuant (version 5.0) software program (Molecular Dynamics, Sunnyvale, CA, USA). Signal intensities of the mouse AR protein were normalized to the gels stained with Coomassie blue as ratios to produce arbitrary densitometric units (ADU) of relative abundance. To standardize the assay for the measurement of AR proteins, we examined different starting protein concentrations for individual sample. This study demonstrated the linearity and validity of ADU for all immunoreactive bands in western blot analysis (Shao et al. 2006). All steps were carried out at room temperature, unless otherwise stated.

\section{Serum assays}

In the 4-month-old untreated mice (Experiment 1), 3 weeks after inactivation of the Iff1 gene in hepatocytes using PiPc, serum IGF1 level was determined from the blood collected from the tip of the tail between 0900 and $1000 \mathrm{~h}$. In the mice that received 5-week treatment (sham/ORX vehicle/ORX DHT; Experiment 2), blood for the analysis of IGF1, estradiol, and testosterone was collected by heart puncture at the end of the 5-week treatment between 1000 and $1500 \mathrm{~h}$. All samples were rapidly put on ice, centrifuged, and then stored in $-80^{\circ} \mathrm{C}$ until analysis. There was no difference between treatment groups or between LI-IGF1 ${ }^{-/-}$and control mice in the timing of the samples.

All serum assays were performed using commercially available kits. Serum IGF1 level was measured by a double-antibody IGFBP-blocked RIA (Mediagnost, Tubingen, Germany). Serum estradiol concentration was analyzed using RIA (Diagnostic Systems Laboratories Inc, Webster, TX, USA). Serum testosterone concentration was determined using RIA (MP Biomedicals, Eschwege, Germany).

\section{Real-time PCR (RT-PCR)}

Total RNA from the VP lobes was extracted by Tri reagent (Sigma) and further purified using spin columns from RNeasy Total RNA Isolation kit (Qiagen), according to the manufacturer's instructions. The RNA was reverse transcribed into cDNA, and then RT-PCR analyses were performed using the ABI PRISM 7700 Sequence Detection System (PE Applied Biosystems, Stockholm, Sweden) using probes labeled with the reporter fluorescent dye FAM. The RT-PCR analyses were performed on prostate tissue samples from individual mice (control mice $(n=6)$ and LI-IGF1 ${ }^{-\prime-}$ mice $(n=8)$ ). The assays, which were used in the RT-PCR analyses, are described in Table 1 (PE Applied Biosystems). The reporter fluorescent dye VIC, specific for $18 \mathrm{~S}$ rRNA, was included in the reactions as an internal standard. The cDNA was amplified at the following conditions: 1 cycle at $50^{\circ} \mathrm{C}$ for $2 \mathrm{~min}$ and $95^{\circ} \mathrm{C}$ for $10 \mathrm{~min}$, followed by 40 cycles at $95^{\circ} \mathrm{C}$ for $15 \mathrm{~s}$ and $60^{\circ} \mathrm{C}$ for $1 \mathrm{~min}$. The amount of mRNA for each gene was calculated using the A Standard Curve Method (multiplex reaction, following the instructions in User Bulletin \#2; PE Applied Biosystems) and adjusted for the expression of $18 \mathrm{~S}$ rRNA.

Table 1 The assays from Applied Biosystems used in the RT-PCR analyses of prostate tissue samples

\begin{tabular}{lll} 
Accession number & & $\begin{array}{l}\operatorname{TaqMan}^{\circledR} \text { assay } \\
\text { identification } \\
\text { number }\end{array}$ \\
\cline { 1 - 1 } NM_013476 & & Mm00442688_m1 \\
NM_007956 & & Mm00433149_m1 \\
NM_010157 & & Mm00599819_m1 \\
NM_184052 & & Mm00439559_m1
\end{tabular}

Journal of Endocrinology (2008) 199, 489-497 


\section{Statistical analyses}

All the descriptive statistical results are presented as the mean \pm S.E.M. Between-group differences were calculated using unpaired $t$-tests. A two-tailed $P<0.05$ was considered significant.

\section{Results}

\section{Inactivation of liver-derived IGF1}

In all experiments, liver-specific inactivation of the Igf1 gene was induced at 4 weeks of age as described in the Materials and Methods section.

Experiment 1: prostate weight, histology, immunohistochemistry, and $A R$ protein level

Prostate weight In 4-month-old control $(n=8)$ and LI-IGF1 $^{-/-}(n=8)$ mice, serum IGF1 concentration was reduced by $73 \%$ in the $\mathrm{LI-IGF} 1^{-/-}$mice, whereas body weight was similar in both groups (Table 2). Prostate and the SV weights were lower in the LI-IGF1 ${ }^{-/}$mice compared with the control mice (total prostate $-31 \%, P<0 \cdot 001$; AP lobe $-19 \%, P<0 \cdot 05$; DLP lobe $-35 \%, P<0 \cdot 01$; VP lobe $-47 \%, P<0 \cdot 01$, and SV $-26 \%, P<0 \cdot 01$; Table 2). All the reductions in prostate and SV weights in the LI-IGF1 ${ }^{-1-}$ mice remained also after correction for body weight (Table 2).

Effects of liver-derived IGF1 on the glandular and fibromuscular components of the prostate gland In the glandular compartment of the DLP and VP lobes, there was a reduction in luminal size and the secretory activity of the epithelium appeared diminished in the 4-month-old LI-IGF1 ${ }^{-/-}$mice compared with the controls (Fig. 1A). The fibromuscular stromal compartment (FMS) was reduced in the
LI-IGF1 ${ }^{-/-}$prostate, with a reduction in FMS surrounding individual glandular structures in the DLP and VP lobes (Fig. 1A). In the LI-IGF1 ${ }^{-/-}$mice, the reductions in both the glandular and fibromuscular compartments of the DLP and VP lobes resulted in reduced total cross-sectional areas of these lobes that were proportional to the observed reductions in individual lobe weights (Table 2).

Immunohistochemical localization of AR in prostate Both the DLP and VP lobes of 4-month-old control mice displayed nearly uniform nuclear AR staining (moderate to intense) of glandular epithelial cells (Fig. 1B). By contrast, nuclear AR staining in the glandular epithelium of both the DLP and VP lobes of the LI-IGF1 ${ }^{-/}$mice was non-uniform and less intense (bottom row). A majority of stromal cells in the DLP and VP of control mice displayed moderate-to-intense AR nuclear staining. In the stromal compartment of LI-IGF1 ${ }^{-/-}$ prostate, a more heterogenic AR staining pattern was observed (Fig. 1B). The same pattern was seen in the SV (not shown). In the AP lobe (also known as coagulating gland) a moderate and non-uniform nuclear staining in epithelial and stromal cells was seen in both $\mathrm{LI}_{-\mathrm{IGF}}{ }^{-/-}$and control mice (Fig. 1B).

Liver-derived IGF1 regulates AR protein level in VP In the 4-month-old mice that had received no treatment, AR protein level in VP tissue was analyzed using western blot analysis. These analyses showed a 30\% reduction, both in terms of absolute and relative levels, of AR protein level in the VP of the LI-IGF1 ${ }^{-/-}$mice compared with the control mice (Fig. 2).

\section{Experiment 2: DHT treatment and $\mathrm{Ar} m \mathrm{~m} N A$ level}

Liver-derived IGF1 modulates the response to DHT treatment on VP weight At 3 months of age, control and LI-IGF1 ${ }^{-/-}$mice were started on treatment with the non-aromatizable androgen dihydrotestosterone (DHT;

Table 2 Serum IGF1, body weight, prostate weight, and weight of the seminal vesicle in 4-month-old control $(n=8)$ and LI-IGF1 ${ }^{-/-}(n=8)$ mice

\author{
Serum IGF1 (ng/ml) \\ Body weight (g) \\ Absolute weight \\ Total prostate weight $(\mathrm{mg})$ \\ Anterior lobe (mg) \\ Dorsolateral lobe $(\mathrm{mg})$ \\ Ventral lobe (mg) \\ Weight of seminal vesicle $(\mathrm{mg})$ \\ Relative weight \\ Total prostate weight (\% of BW) \\ Anterior lobe (\% of BW) \\ Dorsolateral lobe (\% of BW) \\ Ventral lobe (\% of BW) \\ Weight of seminal vesicle (\% of BW)
}

\begin{tabular}{|c|c|c|}
\hline Control mice & LI-IGF1 $^{-1-}$ mice & $P$ value \\
\hline $267(10)$ & $73(5)$ & $<0.001$ \\
\hline $23 \cdot 2(1 \cdot 0)$ & $23 \cdot 0(0 \cdot 8)$ & $0 \cdot 83$ \\
\hline $62 \cdot 2(2 \cdot 0)$ & $42 \cdot 9(2 \cdot 4)$ & $<0 \cdot 001$ \\
\hline $25 \cdot 8(1 \cdot 2)$ & $20 \cdot 8(1 \cdot 7)$ & $<0 \cdot 05$ \\
\hline $23 \cdot 4(1 \cdot 4)$ & $15 \cdot 2(1 \cdot 6)$ & $<0 \cdot 01$ \\
\hline $13 \cdot 0(1 \cdot 6)$ & $6 \cdot 9(0 \cdot 7)$ & $<0 \cdot 01$ \\
\hline $170(7)$ & $126(9)$ & $<0 \cdot 01$ \\
\hline $0 \cdot 271(0 \cdot 014)$ & $0 \cdot 187(0 \cdot 009)$ & $<0 \cdot 001$ \\
\hline $0 \cdot 112(0 \cdot 005)$ & $0 \cdot 091(0 \cdot 007)$ & $<0 \cdot 05$ \\
\hline $0 \cdot 102(0 \cdot 008)$ & $0 \cdot 066(0 \cdot 007)$ & $<0 \cdot 01$ \\
\hline $0 \cdot 057(0 \cdot 008)$ & $0 \cdot 030(0 \cdot 003)$ & $<0 \cdot 01$ \\
\hline $0.742(0.051)$ & $0.546(0 \cdot 027)$ & $<0 \cdot 01$ \\
\hline
\end{tabular}


A

Control
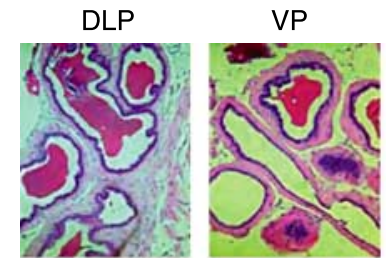

LI-IGF1-/-
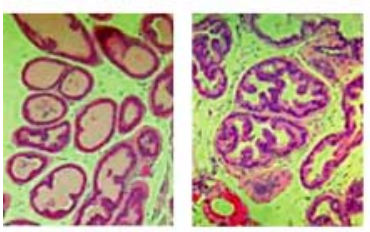

B
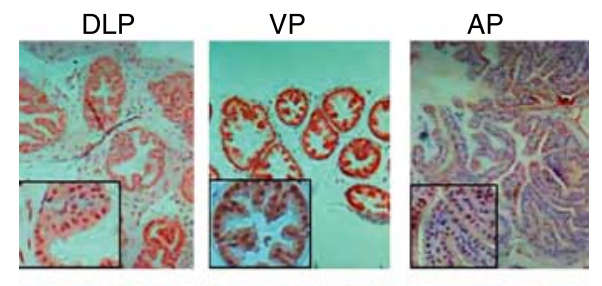

LI-IGF1-/-
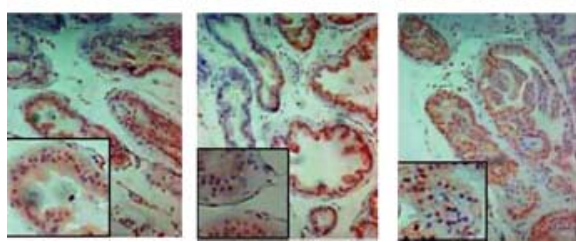

Figure 1 Effects of liver-derived IGF1 on prostate morphology and androgen receptor (AR) immunoreactivity. (A) Representative histological sections (original magnification $100 \times$ ) from 4-month-old LI-IGF1 ${ }^{-/-}$and control mice. A reduction in glandular size, luminal area, and the fibromuscular stromal compartment surrounding the glandular structures was evident in both the dorsolateral prostate (DLP) and ventral prostate (VP) lobes of $\mathrm{LI}-\mathrm{IGF} 1^{-1-}$ mice (bottom row). These reductions in both the glandular and fibromuscular compartments of the VP and DLP lobes were proportional to the reductions in the weights of these lobes. (B) Representative histological sections (original magnification $200 \times$; insets original magnification $400 \times$ ) of prostate glands stained for the AR. Both the DLP and VP of control mice displayed a uniform nuclear AR staining (moderate to intense) in glandular epithelial and stromal cells (top row). By contrast, nuclear AR staining in glandular epithelium and stromal cells of both the DLP and VP of LI-IGF1 ${ }^{-1-}$ mice was nonuniform and less intense (bottom row). In the anterior prostate (AP) lobe (also known as coagulating gland), a moderate and non-uniform nuclear staining in epithelial and stromal cells was seen in both LI-IGF1 ${ }^{-1-}$ and control mice (third column). Full colour version of this figure available via http://dx.doi.org/10.1677/JOE-08-0406

$45 \mu \mathrm{g} /$ day). After 5 weeks, body weight was similar in the sham-operated control and LI-IGF1 ${ }^{-1}$ mice, whereas it was reduced in the ORX vehicle-treated and the ORX DHTtreated LI-IGF1 ${ }^{-/-}$mice (Table 3). In the LI-IGF1 ${ }^{-/-}$ mice, serum IGF1 levels were reduced by $78 \%$ in the shamoperated group, by $74 \%$ in the ORX vehicle-treated group, and by $82 \%$ in the ORX DHT-treated group (Table 3). Serum estradiol and testosterone levels, which were determined only in the sham-operated, gonadal intact mice, were similar in the LI-IGF1 ${ }^{-/-}$and control mice (Table 3).
The mean weight of the VP lobe (the prostate lobe that displayed the most reduced weight in the LI-IGF1 ${ }^{-/-}$mice in Experiment 1) was reduced by 25\% (Fig. 3A) and the mean weight of the SV was reduced by 33\% (Fig. 3B) in the LI-IGF1 ${ }^{-/-}$mice compared with the control mice in the sham-operated group. As expected, the ORX LI-IGF1 ${ }^{-1-}$ and ORX control mice that had received DHT treatment had increased VP and SV weights compared with the vehicle-treated controls (Fig. $3 \mathrm{~A}$ and $\mathrm{B}$ ). Interestingly, VP and SV weights were significantly lower in the DHT-treated LI-IGF1 ${ }^{-1-}$ mice compared with the DHT-treated control mice (Fig. 3A and B). The lower VP and SV weights after DHT treatment in the LI-IGF1 ${ }^{-/-}$mice remained also after correction for body weight (Fig. 3C and D). In the shamoperated group, the reduction in VP weight lost statistical significance after correction for body weight $(-14 \%, P=0 \cdot 2$ versus sham-operated control mice; Fig. $3 \mathrm{C}$ ), whereas the reduction in SV weight remained significant (Fig. 3D).

Liver-derived IGF1 modulates Ar mRNA levels in VP To determine whether the reduced response to androgen treatment with DHT on VP weight in the LI-IGF1 ${ }^{-/-}$mice was associated with decreased $A r$ mRNA level, the levels of $A r$ mRNA in VP tissue were measured using RT-PCR. The sham-operated, gonadal intact LI-IGF1 ${ }^{-/-}$mice displayed a $34 \%$ reduction in the $A r$ mRNA levels in VP when compared with sham-operated, gonadal intact control mice $(P<0 \cdot 05$, Fig. 4A). By contrast, Igf1 mRNA levels in VP were similar in the gonadal intact LI-IGF1 ${ }^{-/-}$mice compared with the gonadal intact controls (Fig. 4B). There was no betweengroup difference in the levels of mRNA coding for estrogen receptor- $\alpha$ or $-\beta$ in the VP (Table 4$)$.

\section{Discussion}

The possible interaction between IGF1 and androgens for the regulation of prostate weight was investigated in the present study. We here demonstrate that deficiency of liver-derived, endocrine IGF1 results in reduced prostate weight due to a proportional reduction in both the glandular and fibromuscular compartments. Deficiency of liver-derived IGF1 also reduced both $A r$ mRNA and protein levels in the prostate, and reduced the stimulatory effect of androgen treatment with DHT on VP weight. These findings demonstrate that IGF1 and androgens interact in the regulation of prostate growth.

Transgenic mice with global inactivation of the Igf 1 gene (Ruan et al. 1999), as well as mice overexpressing a GH antagonist (Ruan et al. 1999), have decreased prostate size (Ruan et al. 1999). However, the role of IGF1 in adult animals is difficult to evaluate in these mice strains due to the possible effect of the absence of IGF1 activity during development. Moreover, there is a local production of IGF1 in the prostate (Kaplan et al. 1999, Meinbach \& Lokeshwar 2006), which is depleted in mice with global IGF1 knockout. By contrast, the LI-IGF1 ${ }^{-/-}$mice do not have decreased liver IGF1 expression until the inactivation 


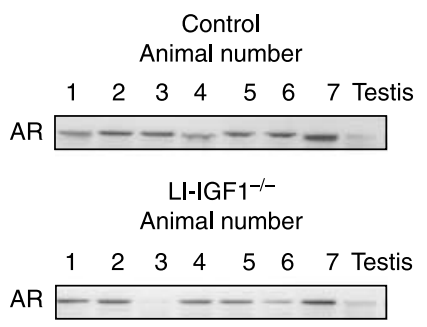

B

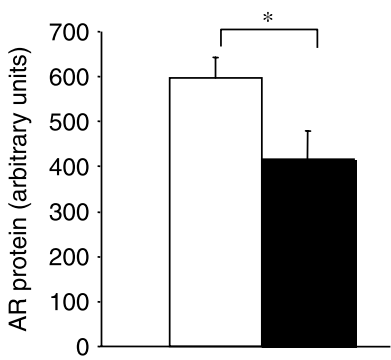

$\square$ Control mice

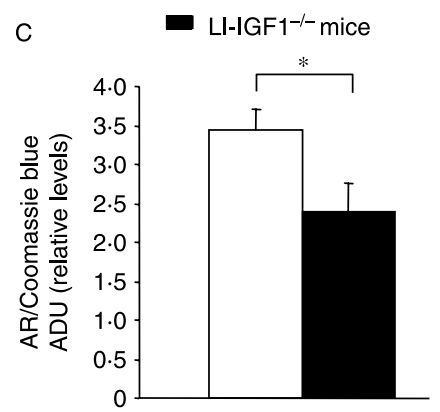

Figure 2 In 4-month-old control $(n=7)$ and LI-IGF1 ${ }^{-1-}(n=7)$ mice, ventral prostate (VP) was split and one half was analyzed using western blot analysis as described in the Materials and Methods section. The $\mathrm{LI}^{-I G F 1^{-/-}}$mice had lower androgen receptor (AR) protein level in VP when compared with the control mice. (A) AR-specific immunoreactivity by western blot analysis. AR protein (110 kDa) in the individual animals is shown. (B) Absolute AR protein expression level. (C) Equal sample loading was confirmed by Coomassie blue staining of gel. Relative levels of AR proteins were calculated as the ratio of AR densitometric value to whole proteins in Coomassie blue staining to produce arbitrary densitometric units (ADU) of relative abundance. In (B) and (C), values are given as means+S.E.M.

at 4 weeks of age and the $I g f 1 \mathrm{mRNA}$ levels, as investigated in the present study, are unaffected in VP. The inactivation of liverderived IGF1 at 4 weeks of age resulted in a marked and maintained reduction in serum IGF1 level. The decreased prostate weight observed in the present study was therefore not, or only to a small extent, due to developmental changes in the prostate or suppressed local IGF1 production in the adult LI-IGF1 $^{-/-}$mice.

Acromegalic patients, who have high serum levels of both GH and IGF1, have increased prostate size (Colao et al. 1998). Conversely, prostate size is decreased when compared with controls in GH-deficient adult humans with low serum GH and IGF1 values (Colao et al. 2003), and GH replacement therapy increases both serum IGF1 levels and prostate size in these patients (Colao et al. 2003). These clinical findings demonstrate that $\mathrm{GH}$ has the capacity to increase prostate size, but they do not establish whether this effect is mediated via IGF1. The LI-IGF1 ${ }^{-/-}$mice have an $\sim 80 \%$ reduction in serum IGF1 concentration and compensatory increased $\mathrm{GH}$ secretion with a geometric mean plasma GH level $3 \cdot 1$ times higher than that in control mice (Sjögren et al. 1999, Wallenius et al. 2001). The present results, with decreased prostate size in the LI-IGF1 ${ }^{-\prime-}$ mice, suggest that circulating
GH cannot increase prostate size without a concomitant increase in circulating IGF1, and that the combination of high circulating $\mathrm{GH}$ and low circulating IGF1 even results in decreased prostate size. Therefore, the increased prostate size in acromegaly and during GH replacement in GH-deficient humans is likely due to the increased serum IGF1 levels.

In adults with GH deficiency and low serum IGF1 values, combined GH and testosterone treatment has additive effects on prostate size (Colao et al. 2003). In the present study, the response to androgen treatment with DHT on VP weight was determined. DHT treatment was given because DHT, in contrast to testosterone, cannot be aromatized to estrogens and therefore stimulates the AR without any effect on estrogen receptors. After the 5-week DHT treatment, VP weight was reduced in ORX mice with inactivation of liverderived IGF1 compared with ORX control mice, demonstrating that liver-derived IGF1, in vivo, modulates the androgenic response on VP weight.

Ar mRNA and protein levels in VP tissue were evaluated to determine whether the reduced response to DHT treatment on VP weight in the LI-IGF1 ${ }^{-/}-$mice was caused by a reduced AR expression. The RT-PCR and western blot analyses showed clearly reduced $\mathrm{mRNA}$ and protein levels

Table 3 Body weight and serum concentrations of IGF1, estrogen, and testosterone after 5-week treatment (sham/ORX vehicle/ORX DHT) in control and LI-IGF1 ${ }^{-1-}$ mice

\begin{tabular}{|c|c|c|c|c|c|c|}
\hline & \multicolumn{2}{|c|}{ Sham (gonadal intact) } & \multicolumn{2}{|c|}{ ORX (vehicle-treated) } & \multicolumn{2}{|c|}{ ORX (DHT-treated) } \\
\hline & Control & LI-IGF1 $^{-/-}$ & Control & $\mathrm{LI}^{-I G F} 1^{-/-}$ & Control & $\mathrm{LI}^{\prime-I G F 1}{ }^{-/-}$ \\
\hline Body weight (g) & $27 \cdot 6(1 \cdot 3)$ & $25 \cdot 0(0 \cdot 8)$ & $25 \cdot 2(0 \cdot 8)$ & $22 \cdot 1(0 \cdot 5)^{\dagger}$ & $29 \cdot 5(0 \cdot 8)$ & $26 \cdot 1(1 \cdot 1)^{*}$ \\
\hline Serum IGF1 (ng/ml) & $245(9)$ & $54(5)^{\ddagger}$ & $250(10)$ & $65(10)^{\ddagger}$ & $211(14)$ & $39(4)^{\ddagger}$ \\
\hline Estradiol (pg/ml) & $10 \cdot 5(0 \cdot 6)$ & $12 \cdot 7(0 \cdot 8)$ & ND & ND & ND & ND \\
\hline Testosterone $(\mathrm{ng} / \mathrm{ml})$ & $2 \cdot 23(0 \cdot 48)$ & $2 \cdot 50(1 \cdot 04)$ & ND & ND & ND & ND \\
\hline
\end{tabular}

Values are given as means (S.E.M.) for $6-8$ animals/group. ORX, orchidectomized; DHT, dihydrotestosterone; ND, not determined. $* P<0 \cdot 05,{ }^{\dagger} P<0 \cdot 01$, ${ }^{\ddagger} P<0 \cdot 001$ versus control mice that had received the same treatment. 

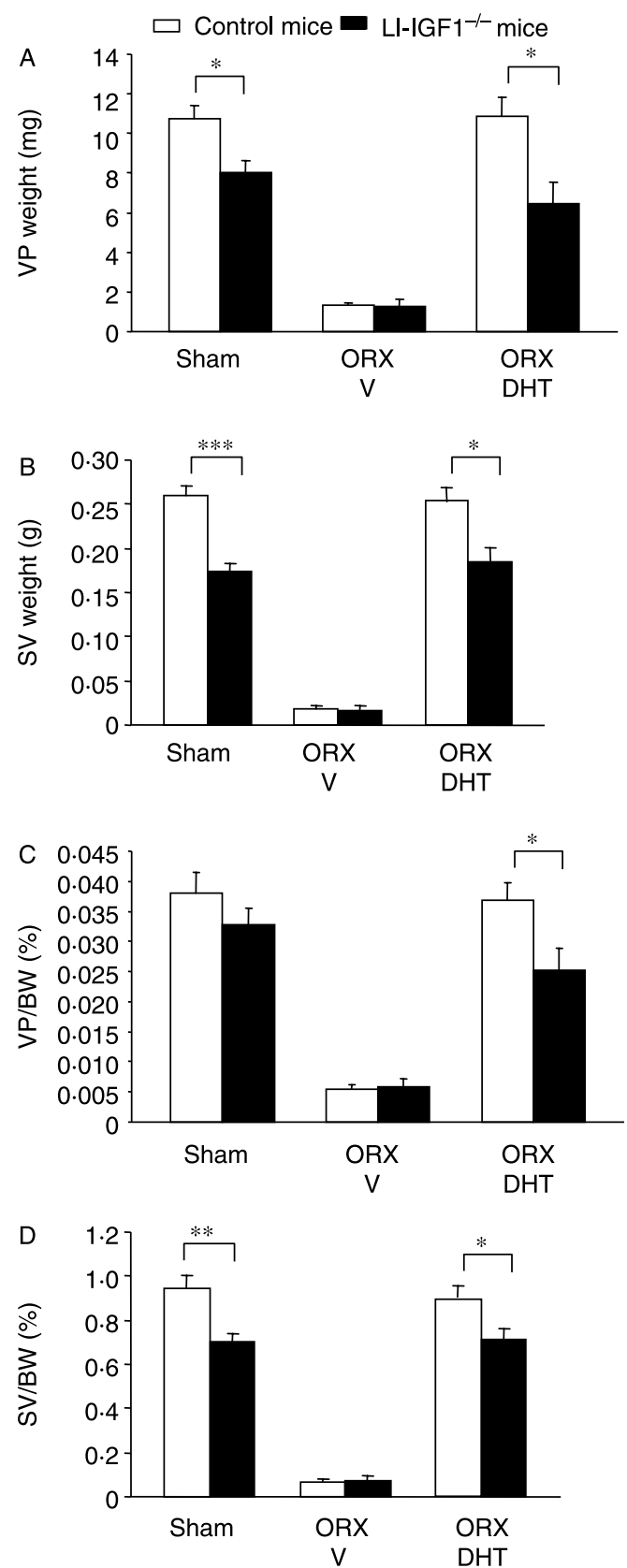

Figure 3 (A) The wet weight of the ventral prostate (VP) lobes, (B) the wet weight of the seminal vesicle, $(C)$ relative weight of the VP lobes (\% of body weight), and (D) relative weight of the seminal vesicle (SV) (\% of body weight) in control and LI-IGF1 ${ }^{-1-}$ mice 5 weeks after the mice had been sham operated or orchidectomized (ORX). The ORX mice had, after the ORX, received 5-week treatment with either vehicle $(\mathrm{V})$ or the non-aromatizable androgen dihydrotestosterone (DHT; $45 \mu \mathrm{g} /$ day) administered via s.c. silastic implants. Values are given as means + s.E.M. ORX, orchidectomized; $\mathrm{V}$, vehicle; $\mathrm{DHT}$, dihydrotestosterone; $\mathrm{VP}$, ventral prostate; $\mathrm{SV}$, seminal vesicle; $B W$, body weight. ${ }^{*} P<0 \cdot 05,{ }^{* *} P<0 \cdot 01$,

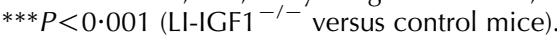

A

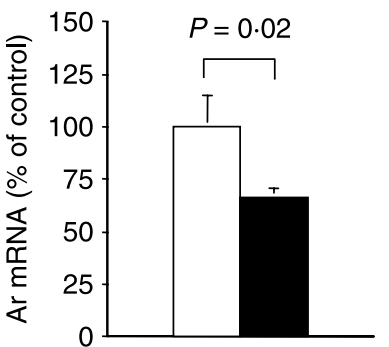

B

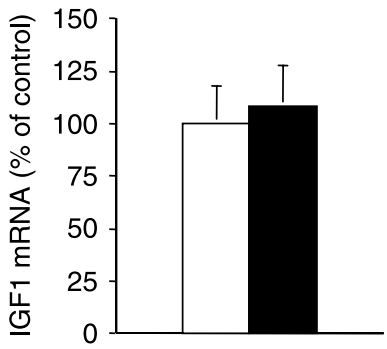

Figure 4 The mRNA levels of $(A)$ the androgen receptor $(A R)$ and $(B)$ IGF1 in ventral prostate of gonadal intact LI-IGF1 ${ }^{-/-}$mice $(n=8)$ expressed as the percentage of those in gonadal intact control mice $(n=6)$. The RT-PCR analyses were performed on tissue samples from individual mice. Values are given as means + S.E.M.

respectively, in VP tissue in the LI-IGF1 ${ }^{-/-}$mice. Reduced nuclear AR staining in both glandular epithelium and stromal cells was also seen in the VP and DLP lobes of the LI-IGF1 ${ }^{-/-}$mice using immunohistochemistry. Taken together, these findings suggest that deficiency of liverderived IGF1 results in reduced AR synthesis in the prostate both in terms of mRNA and protein levels. This downregulation of AR expression in prostate provides one plausible explanation for the reduced response to androgen treatment with DHT on VP weight in the LI-IGF1 ${ }^{-1-}$ mice.

The reduction in AR expression in the prostate of the LI-IGF1 ${ }^{-/-}$mice was not caused by changes in circulating sex steroids as serum levels of testosterone and estradiol were unchanged in the LI-IGF1 ${ }^{-/-}$mice. Furthermore, the mRNA levels of IGF1 as well as those of estrogen receptor- $\alpha$ and $-\beta$ were unaffected in VP tissue of the LI-IGF1 ${ }^{-\prime-}$ mice. However, IGFBP3 may regulate the bioavailability of IGF1, and in addition, IGFBP3 may exert IGF-independent effects on the prostate (Liu et al. 2007). Although serum IGFBP3 concentration was not measured in the present study, we have previously observed an $86 \%$ reduction in serum IGFBP3 level in the LI-IGF1 ${ }^{-/-}$mice (Sjögren et al. 2002). Thus, serum levels of IGF1 as well as IGFBP3 are markedly reduced in the LI-IGF1 ${ }^{-/-}$mice. The importance of the reduction in serum IGFBP3 level is not fully clear, but it can be concluded

Table 4 The mRNA levels of estrogen receptor- $\alpha$ and $-\beta$ in the ventral lobe of the prostate of LI-IGF1 ${ }^{-1-}$ mice $(n=8)$ expressed as the percentage of those in control mice $(n=6)$. The RT-PCR analyses were performed on tissue samples from individual mice.

\begin{tabular}{|c|c|c|c|}
\hline & Control mice & LI-IGF1 $^{-/-}$mice & $P$ value \\
\hline $\begin{array}{l}\text { Estrogen receptor- } \alpha \\
\quad(\% \text { of control) }\end{array}$ & $100(10)$ & $114(11)$ & $0 \cdot 41$ \\
\hline $\begin{array}{l}\text { Estrogen receptor- } \beta \\
\quad(\% \text { of control) }\end{array}$ & $100(9)$ & $101(13)$ & 0.98 \\
\hline
\end{tabular}

Values are given as means (S.E.M). 
that in the LI-IGF1 ${ }^{-/-}$mice, the reduced prostate size and downregulated AR expression in prostate are unlikely to be due to an IGFBP3-mediated inhibition of IGF1 activity.

The prostate is composed of two compartments: glandular and fibromuscular. In a previous study, mice with global inactivation of the Igf1 gene displayed impaired development of the glandular prostate compartment (Ruan et al. 1999). In a later study, it was shown that IGF1 can affect the development of both prostate compartments (Kleinberg et al. 2007). In the present study, there were reductions in glandular size and luminal area, as well as a reduction in the FMS compartment surrounding the glandular structures in the VP and DLP lobes of LI-IGF1 ${ }^{-/-}$mice. These reductions in both the glandular and fibromuscular compartments in the VP and DLP lobes by liver-derived IGF1, which were proportional to the reductions in the weights of these lobes, raise the possibility that IGF1 inhibition could be useful in benign prostatic hyperplasia. This needs, however, to be further investigated in future studies.

In the present study, the importance of liver-derived IGF1 for prostate weight and AR expression in the prostate was studied, but it was not investigated whether prostate cancer development was affected in the LI-IGF1 ${ }^{-/-}$mice. Previous studies in the transgenic adenocarcinoma of the mouse prostate model have suggested that in addition to low levels of circulating IGF1, low GH levels may also be needed to reduce prostate cancer progression (Majeed et al. 2005, Anzo et al. 2008). In vitro studies suggest that IGF1 and androgens may interact in prostate cancer cells (Culig et al. 1994, Pandini et al. 2005), and in humans, in epidemiological studies, a high serum IGF1 level is a risk factor for the development of prostate cancer (Mantzoros et al. 1997, Chan et al. 1998, Wolk et al. 1998). Preliminary studies have been initiated in which the action of the GH/IGF1 system is antagonized. These studies suggest that the blockade of GH/IGF1 or the IGF1 receptor may reduce prostate tumor cell progression (Djavan et al. 2001, Jerome et al. 2003, Samani et al. 2007), but further studies are needed to explore whether the blockade of serum IGF1 could be a complement to surgical or medical androgen ablation therapy for prostate cancer.

In conclusion, we here demonstrate, in the face of unchanged local IGF1 expression, that deficiency of liverderived, endocrine IGF1 decreases AR expression in prostate and reduces $\mathrm{VP}$ growth in response to androgen treatment with DHT. One could therefore speculate that liver-derived IGF1 induces increased AR expression in the prostate, resulting in an enhanced response to androgens on prostate weight. Further studies are needed to evaluate whether systemic blockade of circulating IGF1 will be useful as a complement to other treatments targeting the androgenic pathway in men with benign prostate hyperplasia and/or prostate cancer.

\section{Declaration of interest}

The authors declare that there is no conflict of interest that could be perceived as prejudicing the impartiality of the research reported.

\section{Funding}

This study was supported by the Swedish Research Council (no. K2007-54X09894-16-3), Swedish Society for Medical Research, the Swedish Foundation for Strategic Research, Sahlgrenska Center for Cardiovascular and Metabolic Research (CMR, no. A305:188), the Lundberg Foundation, the Torsten and Ragnar Söderberg's Foundation, Petrus and Augusta Hedlunds Foundation, the Magnus Bergvall Foundation, the Tore Nilsson Foundation, the Novo Nordic Foundation, and Katholieke Universiteit Leuven Grant OT/01/39. Dirk Vanderschueren is a senior clinical investigator of the Fund for Scientific Research-Flanders, Belgium.

\section{Acknowledgements}

We thank Maud Petterson and Lotta Uggla for their excellent technical assistance.

\section{References}

Anzo M, Cobb L, Hwang D, Mehta H, Said J, Yakar S, LeRoith D \& Cohen P 2008 Targeted deletion of hepatic Igf1 in TRAMP mice leads to dramatic alterations in the circulating insulin-like growth factor axis but does not reduce tumor progression. Cancer Research 68 3342-3349.

Chan J, Stampfer M, Giovannuci F, Gann P, Ma J, Wilkinson P, Hennekens C \& Pollak M 1998 Plasma insulin-like growth factor-I and prostate cancer risk: a prospective study. Science 279 563-566.

Cohen P, Peehl D, Lamson G \& Rosenfeld R 1991 Insulin-like growth factors (IGFs), IGF receptors, and IGF binding proteins in primary culture of prostate epithelial cells. Journal of Clinical Endocrinology and Metabolism 73 401-407.

Cohen P, Graves H, Peehl D, Kamarei M, Guidice L \& Rosenfeld R 1992 Prostate-specific antigen (PSA) is an insulin-like growth factor binding protein-3 protease found in seminal plasma. Journal of Clinical Endocrinology and Metabolism 75 1046-1053.

Cohen P, Peehl D \& Rosenfeld R 1994a The IGF axis in the prostate. Hormone and Metabolic Research 26 81-84.

Cohen P, Peehl D, Graves H \& Rosenfeld R $1994 b$ Biological effects of prostate specific antigen as an insulin-like growth factor binding protein-3 protease. Journal of Endocrinology 1994 407-415.

Cohen P, Peehl D, Baker B, Liu F, Hintz R \& Rosenfeld R 1994c Insulin-like growth factor abnormalities in prostate stromal cells from patients with benign prostatic hyperplasia. Journal of Clinical Endocrinology and Metabolism 79 1410-1415.

Colao A, Marzullo P, Ferone D, Spiezia S, Cerbone G, Marino V, Di Sarno A, Merola B \& Lombardi G 1998 Prostate hyperplasia: an unknown feature of acromegaly. Journal of Clinical Endocrinology and Metabolism 83 775-779.

Colao A, Di Somma C, Spiezia S, Filippella M, Pivonelli R \& Lombardi G 2003 Effect of growth hormone (GH) and/or testosterone replacement on the prostate in GH-deficient adult patients. Journal of Clinical Endocrinology and Metabolism 88 88-94.

Culig Z, Hobisch A, Cronauer M, Radmayr C, Trapman J, Hittmair A, Bartsch G \& Klocker H 1994 Androgen receptor activation in prostatic tumor cell lines by insulin-like growth factor-I, keratinocyte growth factor, and epidermal growth factor. Cancer Research 15 5474-5478.

Djavan B, Waldert M, Seitz C \& Marberger M 2001 Insulin-like growth factors and prostate cancer. World Journal of Urology 19 225-233.

Jerome L, Shiry L \& Leyland-Jones B 2003 Deregulation of the IGF-I axis in cancer: epidemiological evidence and potential therapeutical interventions. Endocrine-Related Cancer 10 561-578.

Kanety B, Madjar Y, Dagan Y, Levi J, Papa M, Pariente C, Goldwasser B \& Karasik A 1993 Serum insulin-like growth factor-I-binding protein-2 (IGFBP-2) is increased and IGFBP-3 is decreased in patients with prostate cancer: correlation with serum prostate specific antigen. Journal of Clinical Endocrinology and Metabolism 77 229-233. 
Kaplan P, Mohan S \& Cohen P 1999 The insulin-like growth factor axis and prostate cancer: lessons from the transgenic adenocarcinoma of mouse prostate (Tramp) model. Cancer Research 59 2203-2209.

Kindblom J, Dillner K, Ling C, Törnell J \& Wennbo H 2002 Progressive prostate hyperplasia in adult prolactin transgenic mice is not dependent on elevated serum androgen levels. Prostate 53 24-33.

Kindblom J, Dillner K, Sahlin L, Robertson F, Ormandy C, Törnell J \& Wennbo H 2003 Prostate hyperplasia in a transgenic mouse with prostatespecific expression of prolactin. Endocrinology 144 2269-2278.

Kleinberg D, Ruan W, Yee D, Kovacs T \& Vidal S 2007 Insulin-like growth factor (IGF)-I controls prostate fibromuscular development: IGF-I inhibition prevents both fibromuscular and glandular development in eugonadal mice. Endocrinology 148 1080-1088.

Kuhn R, Schwenk F, Aguet M \& Rajewsky K 1995 Inducible gene targeting in mice. Science 269 1427-1429.

Lam J, Leppert J, Vemulapalli S, Shvarts O \& Belldegrun A 2006 Secondary hormonal therapy for advanced prostate cancer. Journal of Urology 175 $27-34$.

Liu J, Grinberg A, Westphal H, Sauer B, Accili D, Karas M \& LeRoith D 1998 Insulin-like growth factor-I affects perinatal lethality and postnatal development in a gene dosage-dependent manner: manipulation using the Cre/loxP system in transgenic mice. Molecular Endocrinology 12 1452-1462.

Liu B, Lee KW, Anzo M, Zhang B, Zi X, Tao Y, Shiry L, Pollak M, Lin S \& Cohen P 2007 Insulin-like growth factor-binding protein-3 inhibition of prostate cancer growth involves suppression of angiogenesis. Oncogene $\mathbf{2 6}$ 1811-1819.

Majeed N, Blouin M, Kaplan-Lefko P, Barry-Shaw J, Greenberg N, Gaudreau P, Bismar T \& Pollak M 2005 A germ line mutation that delays prostate cancer progression and prolongs survival in a murine prostate cancer model. Oncogene 24 4736-4740.

Mantzoros C, Tzonou A, Signorello L, Stampfer M, Trichopoulos D \& Adami H 1997 Insulin-like growth factor 1 in relation to prostate cancer and benign prostatic hyperplasia. British Journal of Cancer 76 115-118.

Meinbach D \& Lokeshwar B 2006 Insulin-like growth factors and their binding proteins in prostate cancer: cause of consequence? Urologic Oncology 24 294-306.

Orme S, MCNally R, Cartwright R \& Belchetz P 1998 Mortality and cancer incidence in acromegaly: a retrospective cohort study. United Kingdom Acromegaly Study Group. Journal of Clinical Endocrinology and Metabolism $\mathbf{8 3}$ 2730-2734.

Pandini G, Mineo R, Frasca F, Roberts CJ, Marcelli M, Vigneri R \& Belfiore A 2005 Androgens up-regulate the insulin-like growth factor-I receptor in prostate cancer cells. Cancer Research 65 1849-1857.

Perkel V, Mohan S, Baylink D \& Linkhart T 1990 An inhibitory insulin-like growth factor binding protein (IN-IGFBP) from human prostatic cell conditioned medium reveals $\mathrm{N}$-terminal sequence identity with bone derived IN-IGFBP. Journal of Clinical Endocrinology and Metabolism 71 533-535.

Ruan W, Powell-Braxton L, Kopchick J \& Kleinberg D 1999 Evidence that insulin-like growth factor-I and growth hormone are required for prostate gland development. Endocrinology 140 1984-1989.
Samani A, Yakar S, LeRoith D \& Brodt P 2007 The role of the IGF system in cancer growth and metastasis: overview and recent insights. Endocrine Reviews 28 20-47.

Shao R, Weijdegard B, Ljungström K, Friberg A, Zhu C, Wang X, Zhu Y, Fernandez-Rodriguez J, Egecioglu E, Rung E et al. 2006 Nuclear progesterone receptor $\mathrm{A}$ and $\mathrm{B}$ isoforms in mouse fallopian tube and uterus: implications for expression, regulation, and cellular function. American Journal of Physiology. Endocrinology and Metabolism 291 E59-E72.

Shao R, Ljungström K, Weijdegård B, Egecioglu E, Fernandez-Rodriguez J, Zhang F-P, Thurin-Kjellberg A, Bergh C \& Billig H 2007 Estrogeninduced upregulation of AR expression and enhancement of AR nuclear translocation in mouse fallopian tubes in vivo. American Journal of Physiology. Endocrinology and Metabolism 292 E604-E614.

Sjögren K, Liu J, Blad K, Skrtic S, Vidal O, Wallenius V, LeRoith D, Törnell J, Isaksson O, Jansson J-O et al. 1999 Liver-derived insulin-like growth factor I (IGF-I) is the principle source of IGF-I in blood but is not required for postnatal body growth in mice. PNAS 96 7088-7092.

Sjögren K, Wallenius K, Liu J, Bohlooly-Y M, Pacini G, Svensson L, Törnell J, Isaksson O, Ahren B, Jansson J-O et al. 2001 Liver-derived IGF-I is of importance for normal carbohydrate and lipid metabolism. Diabetes $\mathbf{5 0}$ $1539-1545$.

Sjögren K, Sheng M, Moverare S, Liu J, Wallenius K, Törnell J, Isaksson O, Jansson J-O, Mohan S \& Ohlsson C 2002 Effects of liver-derived insulinlike growth factor I on bone metabolism in mice. Journal of Bone and Mineral Research 17 1977-1987.

Tivesten A, Bollano E, Andersson I, Fitzgerald S, Caidahl K, Sjögren K, Skott O, Liu J, Mobini R, Isaksson O et al. 2002 Liver-derived insulin-like growth factor-I is involved in the regulation of blood pressure in mice. Endocrinology 143 4235-4242.

Vandenput L, Boonen S, Van Herck E, Swinnen J, Bouillon R \& Vanderschueren D 2002 Evidence from the aged orchidectomized male rat model that 17 beta-estradiol is a more effective bone-sparing and anabolic agent than 5alpha-dihydrotestosterone. Journal of Bone and Mineral Research 17 2080-2086.

Wallenius K, Sjögren K, Peng X, Park S, Wallenius V, Liu J, Umaerus M, Wennbo H, Isaksson O, Frohman L et al. 2001 Liver-derived IGF-I regulates GH secretion at the pituitary level in mice. Endocrinology 142 4762-4770.

Wolk A, Mantzoros C, Andersson S, Bergström R, Signorello L, Lagiou P, Adami H \& Trichopoulos D 1998 Insulin-like growth factor-1 and prostate cancer risk: a population based, case-control study. Journal of the National Cancer Institute 90 911-915.

Yakar S, Liu J, Stannard B, Butler A, Accili D, Sauer B \& LeRoith D 1999 Normal growth and development in the absence of hepatic insulin-like growth factor I. PNAS 96 7324-7329.

Received in final form 9 September 2008 Accepted 28 September 2008 Made available online as an Accepted Preprint 30 September 2008 